\title{
Fractional electrolyte excretion and osmolality in the early diagnosis of acute kidney injury in cats with urethral obstruction
}

\section{Excreção fracionada de eletrólitos e osmolalidade no diagnóstico precoce de dano renal agudo em gatos com obstrução uretral}

\author{
Francisco Antônio Félix Xavier Júnior ${ }^{1 *}$, Glayciane Bezerra de Morais ${ }^{1}$, Thyago Habner de \\ Souza Pereira ${ }^{2}$, Isadora Oliveira de Carvalho ${ }^{3}$, Fernanda Menezes de Oliveira e Silva ${ }^{4}$, Tiago \\ Lima Sampaio ${ }^{5}$, Alice Maria Costa Martins ${ }^{5}$, Helena Serra Azul Monteiro ${ }^{5}$, Isaac Neto Goes da \\ Silva ${ }^{1}$, Janaina Serra Azul Monteiro Evangelista ${ }^{1}$
}

\begin{abstract}
Acute Kidney Injury (AKI) can be defined as a spectrum of diseases associated with a sudden onset of a renal failure status, the feline patient has azotemia, the disorder in fractional electrolyte excretion (FE), and shedding of epithelial cells from renal tubular segments observed in the urinary sediment. Thus, the objective of the present study was to evaluate the FE, plasma and urinary osmolality, and urinary specific gravity (USG) in cats that spontaneously developed AKI due to urethral obstruction (UO) and healthy cats. Blood and urine samples were collected from a group of 20 cats diagnosed with AKI secondary to urethral obstruction (GAKI; $n=20)$ and clinically healthy cats $(\mathrm{GC} ; \mathrm{n}=15)$. The serum creatinine (sCre) and urinary creatinine (uCre), were measured by spectrophotometry, serum and urinary analyzes of sodium, potassium and chloride by ion selective electrode device and serum and urinary osmolarity by osmometer. The GAKI results were statistically compared with those of the CG using Student's t tests to assess normal data, while the Maan-Whitney test was used for non-normal data. A significant increase in the sCr, sK, FENa, FECl and RFI parameters of the GAKI cats when compared to the GC ( $\mathrm{p}<0.05)$. The $\mathrm{sCl}, \mathrm{USG}, \mathrm{uCr}, \mathrm{uK}$ and uOSM parameters decreased significantly when compared between the two groups. Thus, given the established methodology and the results found, it is possible to infer that an increase in $\mathrm{EFNa}, \mathrm{EFCl}$ in addition to the RFI and a decrease in USG and UOSM were associated with cats with AKI and can serve as markers of kidney damage, as well as monitoring the prognosis.
\end{abstract}

Keywords: acute kidney injury; renal injury; biomarkers; electrolytes; feline.

\section{RESUMO}

A Lesão Renal Aguda (LRA) pode ser definida como um espectro de doenças associadas ao início súbito de um estado de insuficiência renal, o paciente felino tem azotemia, o distúrbio na excreção fracionada de eletrólitos (EF) e liberação de células epiteliais de segmentos tubulares renais observada no sedimento urinário. Assim, o objetivo do presente estudo foi avaliar a EF, osmolalidade plasmática e urinária e a gravidade específica urinária (USG) em gatos que desenvolveram LRA espontaneamente por obstrução uretral (UO) e em gatos saudáveis. Amostras de sangue e urina foram coletadas de um grupo de 20 gatos com diagnóstico de IRA secundária à obstrução uretral (GAKI; $\mathrm{n}=20$ ) e gatos clinicamente saudáveis $(\mathrm{GC} ; \mathrm{n}=15)$. A creatinina sérica ( $\mathrm{sCre}$ ) e a creatinina urinária ( $\mathrm{uCre}$ ), foram mensuradas por espectrofotometria, análises séricas e urinárias de sódio, potássio e cloreto por eletrodo íon seletivo e osmolaridade sérica e urinária por osmômetro. Os resultados do GAKI foram comparados estatisticamente com os do GC usando o teste t de Student para avaliar dados normais, enquanto o teste de Maan-Whitney foi usado para dados não normais. Aumento significativo nos parâmetros sCr, sK, FENa, EFCl e RFI dos gatos GAKI quando comparados ao GC ( $\mathrm{p}<0,05)$. Os parâmetros $\mathrm{sCl}$, USG, uCr, uK e uOSM diminuíram significativamente quando comparados entre os dois grupos. Assim, dada a metodologia estabelecida e os resultados encontrados, é possível inferir que um aumento de EFNa, EFCl além do RFI e uma diminuição 
de USG e uOSM foram associados a gatos com IRA e podem servir como marcadores de lesão renal, bem como monitorar o prognóstico.

Palavras-chave: lesão renal aguda; lesão renal; biomarcadores; eletrólitos; felino.

${ }^{1}$ Faculty of Veterinary Medicine, State University of Ceara, Fortaleza, Brazil. *E-mail: juniorfelix.medicoveterinario@gmail.com

${ }^{2}$ Animal Physiology Laboratory, Federal Rural University of the Amazon, Belém, Brazil

${ }^{3}$ Superior Institute of Biomedical Sciences, State University of Ceara, Fortaleza, Brazil

${ }^{4}$ Health Sciences Center, Faculty of Veterinary, University of Fortaleza, Fortaleza, Brazil

${ }^{5}$ Department of Physiology and Pharmacology, Faculty of Medicine, Federal University of Ceara, Ceara, Brazil

\section{INTRODUCTION}

Functional assessment of the urinary tract is becoming increasingly common in the clinical routine in veterinary medicine due to the ease of sample collection and some advantages over serum tests (Waldrop, 2008). These exams include serum and urinary osmolality, direct and indirect glomerular filtration rate markers, fractional electrolyte excretion, tissue integrity and renal structural damage markers (DiBartola, 2006).

Although serum osmolality (sOsm) and solute concentrations must exist in narrow ranges for proper cell function, urine chemical composition can vary widely. Kidneys alter the urine composition to facilitate normal homeostasis and respond to systemic challenges. Biochemical analysis of urine is vitally important to determine if kidneys are functioning properly in order to respond appropriately to insults and injuries (DiBartola, 2006; Waldrop, 2008).

Urinary volume and elements depend on urinary actions in blood filtration, in addition to the reabsorption and secretion of water and solutes. As plasma passes through the glomerulus, macromolecules (eg, proteins) and cellular elements are selectively retained based on their charge and size (DiBartola, 2006; Waldrop, 2008; Reddi, 2014).

Fractional electrolyte excretion (FE) is defined as a proportion of filtered solute that is not recovered when it passes through the renal tubular system. (DiBartola, 2006; Waldrop, 2008; Reddi, 2014). FE has been used as a readily available and cost-effective marker of tubular damage and renal function in dogs with acute kidney injury (AKI). Recent studies have shown that fractional excretion of sodium (FENa) is an early marker of tubular damage resulting from pre-renal and renal AKI in dogs (Brown et al., 2015; Segev et al., 2015; Troia et al., 2018).

In AKI, which is characterized by the sudden onset of a renal failure status, the feline patient has azotemia, increased FENa, and shedding of epithelial cells from renal 
tubular segments observed in the urinary sediment (Brown et al., 2015; Segev et al., 2015; Xavier Junior et al., 2019). The main causes include prolonged and indiscriminate use of nephrotoxic drugs such as non-steroidal anti-inflammatory drugs and chemotherapy, infectious processes, vasculitis, neoplasms and urinary tract obstruction (Brown et al., 2015; Segev et al., 2015; Troia et al., 2015; Troia et al., 2015; Troia et al., 2015; Troia et al., 2015; al., 2018). Among these causes, urethral obstruction (UO) is an important trigger of AKI in cats as it can be triggered by urethral plugs and sediment accumulation that obliterate the urinary flow in the urethra resulting from cystitis, inflammation process common in feline species (Segev et al., 2013; Xavier Junior et al., 2019).

In feline medicine, studies attest to the lack of data regarding the evaluation of these urinary tests in cats that developed AKI compared to healthy cats. Therefore, the aim of the present study was to evaluate the FE, plasma and urinary osmolality and urinary specific gravity in cats that spontaneously developed AKI due to UO.

\section{MATERIALS AND METHODS}

\section{Study Design}

This was a prospective observational case-control study with follow-up in a hospital unit, carried out at the Sylvio Barbosa Cardoso Veterinary Hospital (HVSVC) from State University of Ceara, Fortaleza, Ceará, Brazil, from April 2019 to November 2019.

\section{Study Population}

The study group had thirty-five male cats (Felis catus), without racial predisposition and with different ages composed, being divided into two groups: cats diagnosed with AKI secondary to urethral obstruction (GAKI; n=20) and clinically healthy cats $(\mathrm{GC} ; \mathrm{n}=15)$. All GAKI cats had a diagnosis of AKI by clinical evaluation (such as anuria, oliguria, vomiting and inappetence), associated with laboratory tests (increased serum creatinine, hypostenuria and cylindruria) and kidneys' ultrasonographic evaluation regarding their respective qualitative (echogenicity, architecture, contours and cortico-medullary definition) and quantitative (length, width and area) parameters.

The exclusion criteria for cats to compose the GAKI were the presence of ureteral, bladder and urethral stones; neoplasms and/or congenital anomalies of the urinary tract (based on ultrasound examinations); urinary tract infection (excluded by quantitative 
analysis in culture of urine and previous clinical history); diabetes mellitus; and hyperthyroidism. For GC, data were obtained from clinically healthy cats brought to the same hospital for elective procedures such as spaying and/or vaccination.

All experiments were carried out in accordance with the ethical principles of animal experimentation adopted by the Ethics Committee on the Use of Animals of State University of Ceará (Protocol 02875696/2019). Tutors authorized the use of all clinical data, signing an informed consent form authorizing the collection of serum and urine samples, as well as the performance of abdominal ultrasound and use of data in publications.

\section{Clinical and Clinical Pathological Data}

Clinical and laboratory data were collected and analyzed at the time of AKI diagnosis. Clinical monitoring was performed and recorded throughout hospitalization. Daily clinical data recorded included body weight and temperature; heart and respiratory rate; hydration status/urinary volume; fluid volume administered; and reduced urine output (mL).

Cats received medical treatment and supportive care based on the veterinarians' assessment. All cats belonging to the UO were promptly assisted, stabilized and managed with regard to the urethral clearance process and subsequently hospitalized. Clinical follow-up and procedures such as intravenous fluid therapy, urethral catheterization and methadone-based post urethral clearance analgesia $(0.2 \mathrm{mg} / \mathrm{kg}$; i.v. TID) were performed. Urethral probe was performed after the patient stabilization, asepsis and anesthesia with Methadone $(0.2 \mathrm{mg} / \mathrm{kg}$; im) associated with Acepromazine $(0.02 \mathrm{mg} / \mathrm{kg}$; im) initially, followed by induction by Propofol ( $4 \mathrm{mg} / \mathrm{Kg}$; iv), maintained by Isofuran via the tracheal tube. After the necessary hospitalization period, patients were discharged from the hospital and medications were prescribed to control pain and urethral spasms such as Gabapentin (5 mg/kg BID for 21 days) associated with Tramadol Hydrochloride (1 mg/kg BID for 10 days), Prednisolone (1 mg/kg SID for 7 days), Prazosin $(0.25 \mathrm{mg} / \mathrm{cat}$ BID for 14 days). Dietary prescription guidance was performed with Purina Proplan ${ }^{\circledR}$ UR, following the manufacturer's daily recommendations regarding the animal's weight and improvement in water intake.

Blood samples were collected by standard venipuncture using vacuum blood collection systems; simultaneous urine samples were obtained by cystocentesis. Samples 
were collected, centrifuged (3500 rpm for 15 minutes to obtain serum) and stored in aliquots at $-80{ }^{\circ} \mathrm{C}$ for further analysis. Serum analyzes of creatinine, sodium, potassium, chloride and osmolality were performed. Urine examination included urinary density (USG), osmolality, urinary electrolyte concentration, and fractional electrolyte excretion. Laboratory methods

Serum (sCre) and urinary creatinine (uCre) levels were obtained using an automated biochemical analyzer system (Cobas C111, Roche®) based on the enzymatic colorimetric method and spectrophotometry (Roche® reagents). Urinary density was measured by a manual refractometer (Akso RSG32 optical refractometer) according to the described by Reppas \& Foster, 2016.

All serum and urinary analyzes of sodium, potassium and chloride were performed using an ion selective electrode device (RapidChem 744 - Bayer® diagnostic). Serum and urinary osmolarity was determined using an osmometer (Vapro pressure osmometer - model 5520 WESCOR). Fractional electrolyte excretion (FE), including FE sodium (FENa), FE potassium (FEK) and FE chloride (FECl), and the renal failure index (RFI) were calculated according to Waldrop, 2008.

\section{Statistical Analysis}

Values obtained were organized in spreadsheets (Excel, Microsoft ${ }^{\circ}$ ) and statistical analyzes were performed using the GraphPad Prism software version 8.0.1 for Windows (GraphPad, San Diego, California, USA). Data normality was assessed using the Shapiro-Wilk test and unpaired Student t tests were used to assess normal data, while the Maan-Whitney test was used for non-normal data. Statistical differences between GC and GAKI were evaluated in relation to biochemical parameters (blood and serum creatinine, CPR and urinary density), osmolality and serum, urinary and FE concentration of electrolytes $\mathrm{K}^{+}, \mathrm{Na}^{+}$and $\mathrm{Cl}^{-}$. Values obtained were presented as mean \pm standard deviation $(\mathrm{SD})$, and results with $\mathrm{p}$-value $<0.05$ were considered statistically significant.

\section{RESULTS}

The study population consisted of cats with no defined racial pattern. The mean \pm $\mathrm{SD}$ age of the GAKI cats was $3.05 \pm 1.85$ years while the GC was $2.57 \pm 1.91$ years, respectively. The mean weight of the GAKI cats was $4.51 \pm 1.02 \mathrm{~kg}$ and the GC was 5.07 
$\pm 1.04 \mathrm{~kg}$. There were no significant differences between groups regarding age $(\mathrm{p}=$ $0.4602)$ and body weight $(\mathrm{p}=0.1215)$.

In the GAKI group, twelve cats were neutered $(12 / 20,60 \%)$ and eight were not $(8 / 20,40 \%)$. In the GC, twelve cats were neutered $(12 / 15,80 \%)$ and three were not $(3 / 20$; 20\%). All cats included in the GAKI group had AKI etiology, feline idiopathic cystitis as a cause of obstructive nephropathy (excluding other causes of obstruction), according to clinical, hematological, biochemical, urinary and ultrasonographic parameters.

The results and main significant differences between cats with GAKI and GC groups were reported in Table 1. A significant increase in $\mathrm{sCr}(\mathrm{p}=0.0038), \mathrm{sK}(\mathrm{p}=$ 0.0027), UPC (<0.0001) values was observed in the GAKI group), EFNa and EFCl ( $\mathrm{p}<$ $0.0001)$ in addition to the RFI ( $\mathrm{p}<0.0001)$. However, $\mathrm{sCl}(\mathrm{p}<0.0001)$, USG ( $\mathrm{p}<0.0001)$, $\mathrm{uCr}(\mathrm{p}<0.0001), \mathrm{uK}(\mathrm{p}<0.0001)$ and uOSM $(\mathrm{p}<0.0001)$ values decreased significantly when compared between the two groups. No statistically significant differences were detected in the values of $\mathrm{sNa}(\mathrm{p}=0.4141), \mathrm{uNa}(\mathrm{p}=0.3462), \mathrm{uCl}(\mathrm{p}=0.7752), \mathrm{EFK}(\mathrm{p}=$ $0.7752)$ and $\mathrm{sOSM}(\mathrm{p}=0.8628)$.

Table 1: Descriptive statistics and comparison between GAKI and control group and clinical pathological variables.

\begin{tabular}{c|c|c|c}
\hline Variables & $\begin{array}{c}\text { Control } \\
(\mathbf{n = 1 5})\end{array}$ & $\begin{array}{c}\text { AKI } \\
(\mathbf{n = 2 0})\end{array}$ & P-value \\
\hline $\begin{array}{l}\text { Serum } \\
\text { biochemistry }\end{array}$ & & & \\
\hline Creatinine $(\mathrm{mg} / \mathrm{dL})$ & $1.43 \pm 0.08$ & $7.67 \pm 7.35^{*}$ & 0.0038 \\
\hline Potassium $(\mathrm{mEq} / \mathrm{L})$ & $4.25 \pm 0.27$ & $6.21 \pm 2.31^{*}$ & 0.0027 \\
\hline Sodium $(\mathrm{mEq} / \mathrm{L})$ & $148.30 \pm 8.11$ & $151.10 \pm 10.24$ & 0.4141 \\
\hline Chloride $(\mathrm{mEq} / \mathrm{L})$ & $132.80 \pm 8.6$ & $117.70 \pm 7.58^{*}$ & $<0.0001$ \\
\hline $\mathrm{sOSM}(\mathrm{Osm} / \mathrm{kg})$ & $535.0 \pm 308.4$ & $467.6 \pm 180.5$ & 0.8628 \\
\hline Urinalysis & & & \\
\hline $\mathrm{USG}$ & $1057 \pm 10.14$ & $1024 \pm 5.87^{*}$ & $<0.0001$ \\
\hline $\mathrm{uCr}(\mathrm{mg} / \mathrm{dL})$ & $460.8 \pm 127.7$ & $170.2 \pm 101.7 *$ & $<0.0001$ \\
\hline $\mathrm{UPC}$ & $0.08 \pm 0.03$ & $1.98 \pm 2.34^{*}$ & $<0.0001$ \\
\hline $\mathrm{uK}$ & $97.99 \pm 38.27$ & $46.76 \pm 91.40^{*}$ & $<0.0001$ \\
\hline $\mathrm{uNa}$ & $122.80 \pm 45.48$ & $11.20 \pm 25.99$ & 0.3462 \\
\hline $\mathrm{uCl}$ & $123.00 \pm 65.11$ & $118.30 \pm 30.18$ & 0.7752 \\
\hline $\mathrm{FEK}(\%)$ & $7.80 \pm 3.93$ & $25.08 \pm 42.62$ & 0.1222 \\
\hline $\mathrm{FENa}(\%)$ & $0.29 \pm 0.16$ & $6.51 \pm 8.32^{*}$ & $<0.0001$ \\
\hline $\mathrm{FECl}(\%)$ & $0.31 \pm 0.20$ & $8.40 \pm 10.67^{*}$ & $<0.0001$ \\
\hline $\mathrm{uOSM}(\mathrm{Osm} / \mathrm{kg})$ & $1926.0 \pm 500.3$ & $1071.0 \pm$ & $<0.0001$ \\
& & $518.6 *$ & \\
\hline
\end{tabular}




\begin{tabular}{c|c|c|c}
\hline & & & \\
\hline RFI & $0.42 \pm 0.23$ & $9.33 \pm 11.7 *$ & $<0.0001$ \\
\hline
\end{tabular}

Data are reported as mean \pm SD based on their distribution.

Abbreviations: USG = urinary specific gravity; $\mathrm{uCre}=$ urine creatinine; $\mathrm{UPC}=$ urine protein to creatinine ratio; $\mathrm{uK}=$ urine potassium; $\mathrm{uNa}=$ urine sodium; $\mathrm{uCl}=$ urine chloride; $\mathrm{FEK}=$ fractional excretion of potassium; $\mathrm{FENa}=$ fractional excretion of sodium; $\mathrm{FECl}=$ fractional excretion of chloride; $\mathrm{uOSM}=$ urine osmolality; $\mathrm{sOSM}=$ serum osmolality; RFI = Renal Failure insufficiency.

$* p<0.005$ GAKI vs. GC.

\section{DISCUSSION}

Epidemiological data of the animals in this study were in accordance with the literature, which reports that occluded cats have the profile of animals aged between 1-6 years, with a predominance of mixed-breed animals, and the condition of urethral obstruction is proportionally higher in neutered cats (Segev et al., 2013; Nevins et al., 2015; Neri, et al. 2016; Xavier Junior et al., 2019).

Changes in the post-renal compartment in cats with AKI, secondary to UO, cause body accumulation of nitrogen compounds and retention of serum creatinine. This is due to the creatinine permeability in tubular segments, passively diffusing back into the blood. The amount of creatinine reabsorbed is inversely proportional to the urine flow rate: therefore, there is a reduction in uCre excretion in cats with UO, corroborating our results (Sink \& Weinstein 2012, Reece 2015).

The markers creatinine and USG, used for renal dysfunction assessment, showed a significant difference between GAKI and GC groups. Changes in these parameters were also observed by Bua, Dunn, Pey (2015) in cats with urethral obstruction, with reduced USG $(<1,035)$ and increased sCr levels $(>1.58 \mathrm{mg} / \mathrm{dL}$ ). Cats with USG <1,025 (when followed by dehydration and azotemia) is indicative of decreased renal function. Persistent hyposthenuria is suggestive of a concentration defect in renal tubular segments (De Shepper et al. 1989, Reppas \& Foster 2016a).

In this study, changes in renal solute excretion values and osmolality in cats with naturally occurring AKI due to urethral obstruction were evaluated. Results suggest that the FENa, FECa, uOsm and RFI are parameters that can be used in the clinical setting as markers of renal tubular damage and follow-up for kidney damage.

Significant reductions in urine osmolality and USG were demonstrated in the GAKI group when compared to GC group. Osmolality is responsible for measuring the number of particles dissolved in urine while USG shows both the number and weight of 
urinary particles, being these two determinants usually altered simultaneously (Reddi, 2014).

Measuring sOSM levels is relevant in the differentiation of pre-renal and renal azotemia causes, verifying that at least $33 \%$ of the renal mass is functioning properly (Waldrop, 2008; Lefebvre et al., 2008). A concentrated urine sample (uOsm > 1200 Osm/kg, USG > 1.035) is found when the renal concentration function is adequate; however, a decrease in these values indicates a loss in kidney's urinary capacity, resulting in acute kidney injury due to renal ischemia. Our findings demonstrate a reduction in both uOsm and USG, demonstrating acute kidney injury.

The amount of water in the urine can interfere in the electrolyte levels: a very dilute urine reduces the electrolytes concentration and reading it individually is not recommended. Therefore, the FE of electrolytes becomes a support tool, as there is the exclusion of the water factor by its calculation, offering greater credibility in the electrolytes values (Waldrop, 2008). This can be visualized in the present study, in which potassium levels change in urine dosage in the GAKI group when compared to GC, while FEK did not change significantly between groups. Thus, measuring both serum and urine electrolytes FE can be extremely useful in veterinary practice to assess renal function (Lefebvre et al., 2008).

Electrolyte FE measurements can suffer both endogenous and exogenous interferences, such as feeding, dehydration, and endocrine diseases (Pressler, 2013). Due to this, there are no precisely stipulated "normal" reference values for dogs or cats; however, FENa $<1 \%$ and FEK $\leq 25 \%$ values are generally used for cats (Adams et al., 1991; Corea et al., 1996). FENa is an important tool to monitor kidney diseases in humans, especially in patients with AKI (Reddi, 2014). Our data show a significant increase in FENa in the GAKI group, whose value was greater than 1\%, demonstrating that this marker can also be important in the assessment of kidney injury in cats. There was a tendency towards an increase in FEK, but the results were not significant.

The use of indexes in the medical field has been standardized and there are many online calculators for FENa and RFI (Waldrop, 2008). Although the use of these urinary indices in veterinary medicine has not yet been validated, they can be extrapolated by human values. Therefore, this is the first clinical study to use this measure as a parameter for acute kidney injury. Our results show a significant difference in this index between groups, demonstrating a higher RFI value in cats with GAKI. RFI values $>2$ associated 
with an increase in FENa $>2-3 \%$ indicate acute tubular necrosis, corroborating our findings.

Urinary markers are considered a resource little used in veterinary medicine, despite their wide availability and cost-effectiveness. Interpretation of these markers should be consider expected renal responses and use multiple indices to avoid the limitations associated with a single urine test. Urine biochemistry may be more useful in acute kidney injury cases resulting from processes that develop toxicity or changes in glomerular permeability, such as capillary leak syndrome. Additional research is needed to validate the usefulness of urinary markers for early detection of urinary changes and diseases, which can be associated with laboratory and clinical findings.

\section{CONCLUSIONS}

In conclusion, an increase in $\mathrm{EFNa}, \mathrm{EFCl}$ in addition to the RFI, and a decrease in USG and UOSM have been associated with cats with AKI and may serve as markers of kidney damage as well as monitor prognosis. Thus, these markers should be investigated in a larger cohort to further substantiate these preliminary findings.

\section{ACKNOWLEDGEMENTS}

To Conselho Nacional de Desenvolvimento Científico e Tecnológico (CNPQ); Sylvio Barbosa Cardoso Veterinary Hospital (HVSVC) from State University of Ceara, Fortaleza, Ceará, Brazil for the space availability and collaboration in the research experimental part; and Purina Proplan ${ }^{\circledR}$ for providing feed for the treatment of cats with urinary tract disease.

\section{REFERÊNCIAS}

ADAMS, L.G.; POLZIN, D.J.; OSBORNE, C.A.; O'BRIEN, T.D. Comparison of fractional excretion and 24-hour urinary excretion of sodium and potassium in clinically normal cats and cats with induced chronic renal failure. American Journal of Veterinary Research, v.52, n.5, p.718-22, 1991.

BENNETT, S.L.; ABRAHAM, L.A.; ANDERSON, G.A.; HOLLOWAY, S.A.; PARRY, B.W. Reference limits for urinary fractional excretion of electrolytes in adult non-racing Greyhound dogs. Australian Veterinary Journal, 2006 v.84, n.11, p.393-397. 
BROWN, N.; SEGEV, G.; FRANCEY, T.; KASS, P.; COWGILL, L.D. Glomerular filtration rate, urine production, and fractional clearance of electrolytes in acute kidney Injury in dogs and their association with survival. Journal of Veterinary Internal Medicine, v. 29, n.1, p. 28-34, 2015.

BROWN, S.; ATKINS, C.; BAGLEY, R.; CARR, A.; COWGILL, L.; DAVIDSON, M.; EGNER, B.; ELLIOTT, J.; HENIK, R.; LABATO, M.; LITTMAN, M.; POLZIN, D.; ROSS, L.; SNYDER, P.; STEPIEN, R. Guidelines for the identification, evaluation, and management of systemic hypertension in dogs and cats. Journal of Veterinary Internal Medicine, v.21, n.3, p.542-558, 2007.

BUA, A.; DUNN, M.E.; PEY, P. Respective associations between ureteral obstruction and renomegaly, urine specific gravity, and serum creatinine concentration in cats: 29 cases (2006-2013). Journal of the American Veterinary Medical Association, v. 247, n.5, p.518-524, 2015.

COREA, M.; SEELIGER, E.; BOEMKE, W.; REINHARDT, H.W. Diurnal pattern of sodium excretion in dogs with and without chronically reduced renal perfusion pressure.

Kidney \& Blood Pressure Research, v.19, n.1, p.16-23, 1996.

COTTAM, Y. H.; CALEY, P.; WAMBERG, S.; HENDRIKS, W. H. Feline Reference Values for Urine Composition. The Journal of Nutrition, v.132, n.6, p.1754S-1756S, 2002.

DIBARTOLA, S.P. Fluid, electrolyte and acid-base disorders in small animal practice. $3^{\mathrm{a}}$ ed. St. Louis (MO): Elsevier, 2006. p. 26-46.

FILIPPICH, L.J. Renal clearance studies in cats with chronic renal disease: Dietarv implications. Journal of Small Animal Practice, v.33, p.191-196, 1992.

LEFEBVRE, H.P.; DOSSIN, O.; TRUMEL, C.; BRAUN, J. Fractional excretion tests: a critical review of methods and applications in domestic animals. Veterinary Clinical Pathology, v.37, n.1, p.4-20, 2008.

LOBETTI, R.G. Urinary Fractional Clearance of Sodium in 8 Healthy Beagle Dogs Fed Normal, Low, or Ultralow Sodium Diets. Veterinary Medicine International, v. 2020, $1-5,2020$.

NERI, A.M.; MACHADO, L.H.A.; OKAMOTO, P.T.C.G.; FILIPPI, M.G.; TAKAHIRA, R.K.; MELCHERT, A.; LOURENÇO, M.L.G. Routine screening examinations in attendance of cats with obstructive lower urinary tract disease. Topics in Companion Animal Medicine, v.31, n.4, p.140-145, 2016.

NEVINS, J.R.; MAI, W; THOMAS, E. Associations between ultrasound and clinical findings in 87 cats with urethral obstruction. Veterinary Radiology \& Ultrasound, v. 56, n.4, p.439-447, 2015.

PRESSLER, B.M. Clinical approach to advanced renal function testing in dogs and cats. The Veterinary Clinics of North America. Small Animal Practice, v. 43, n.6, p.1193208, 2013. 
REDDI, A.S. Interpretation of Urine Electrolytes and Osmolality. In: REDDI. A.S.; Fluid, electrolyte and acid-base disorders clinical evaluation and management, 1st ed. Springer; 2014. p. 448.

REPPAS, G.; FOSTER, S.F. Practical urinalysis in the cat 1: Urine macroscopic examination 'tips and traps'. Journal of Feline Medicine and Surgery, v.18, n.3, p.190$202,2016$.

SEGEV, G.; DAMINET, S.; MEYER, E.; DE LOOR, J.; COHEN, A.; AROCH, I.; BRUCHIM, Y. Characterization of kidney damage using several renal biomarkers in dogs with naturally occurring heatstroke. Veterinary Journal, v. 206, n.2, p. 231-235, 2015.

SEGEV, G.; NIVY, R.; KASS, P.H.; COWGILL, L.D. A retrospective study of acute kidney injury in cats and development of a novel clinical scoring system for predicting outcome for cats managed by hemodialysis. Journal of Veterinary Internal Medicine, v.27, n.4, p. 830-839, 2013.

TROIA, R.; GRUARIN, M.; GRISETTI, C.; SERAFINI, F.; MAGNA, L.; MONARI, E.; GIUNTI, M.; DONDI, F. Fractional excretion of electrolytes in volume-responsive and intrinsic acute kidney injury in dogs: diagnostic and prognostic implications. Journal of Veterinary Internal Medicine, v.32, n.4, p. 1372-1382, 2018.

VAN VONDEREN, I.K.; KOOISTRA, H.S.; RIJNBERK A. Intra- and interindividual variation in urine osmolality and urine specific gravity in healthy pet dogs of various ages. Journal of Veterinary Internal Medicine, v.11, 30-35, 1997.

WALDROP, J.E. Urinary Electrolytes, Solutes, and Osmolality. Veterinary Clinics of North America: Small Animal Practice, v.38, 503-512, 2008.

XAVIER JÚNIOR, F.A.F.; MORAIS, G. B.; DUTRA, M.S.; FREITAS, M.M.; ARAUJO, S.L.; VIANA, D.A.; EVANGELISTA, J.S.A.M. Acute Kidney Disease in cats: achievements and challenges. Medicina Veterinária (UFRPE), v.13, n.3, p.352$361,2019$. 